\title{
Objektív vizsgálati lehetőség az idiopathiás és a másodlagos benignus paroxysmalis positionalis vertigo elküilönítésében
}

\author{
Maihoub Stefani dr. - Molnár András dr. - Fent Zoltán dr. \\ Tamás László dr. - Szirmai Ágnes dr.
}

Semmelweis Egyetem, Általános Orvostudományi Kar, Fül-Orr-Gégészeti és Fej-Nyaksebészeti Klinika, Budapest

Bevezetés: A benignus paroxysmalis positionalis vertigo (BPPV) a leggyakoribb belsőfül-eredetű szédüléses kórkép. Legfontosabb tünete a szédülés, amelyet tipikus fejmozdítás vált ki, sok esetben azonban vegetatív tünetek is társulnak. Etiológiája alapján idiopathiás és szekunder (egyéb vestibularis eltéréshez társulva, például Ménière-betegség, neuritis vestibularis) BPPV különíthető el.

Célkitüzés: Kutatásunk célja olyan, kraniokorpográf által vizsgált paraméter azonosítása, amely segíthet az idiopathiás és a szekunder BPPV elkülönítésében.

Anyag és módszer: Kutatásunkba 135, BPPV-ben szenvedő beteget vontunk be, emellett 140 ép egyensúlyrendszerü alanyt is vizsgáltunk ultrahangos-számítógépes kraniokorpográf segítségével. A statisztikai elemzéseket az IBM SPSS V24 szoftver segítségével hajtottuk végre.

Eredmények: 109 betegnél igazolódott idiopathiás, míg 26 beteg esetén szekunder BPPV. A kraniokorpográfos leletek elemzése alapján szignifikáns különbség adódott a 'forehead covering area' (fejmozgás által lefedett terület) és a 'self-spin' (tengely körüli forgás) paraméterekben, ezek gyakrabban kórosak szekunder BPPV esetén.

Következtetés: Az ultrahangos kraniokorpográf segítségével a BPPV modern és objektív diagnosztikája biztosítható, elsősorban a szekunder típusú esetekben.

Orv Hetil. 2020; 161(6): 208-213.

Kulcsszavak: ultrahangos-számítógépes kraniokorpográf, idiopathiás BPPV, szekunder BPPV

\section{Objective diagnostic possibility in the differentiation of idiopathic and secondary benign paroxysmal positional vertigo}

Introduction: Benign paroxysmal positional vertigo (BPPV) is the most common peripheral vestibular disorder. The most important symptom is vertigo, which is triggered by changes in head position and sometimes is accompanied by vegetative symptoms. Furthermore, etiology may be subcategorized into idiopathic and secondary (connected to other vestibular disorder, like Ménière's disease, vestibular neuritis, or vestibular migraine).

Aim: To identify such parameter of ultrasound-computer-craniocorpography (US-COMP-CCG), which could be useful in the differentiation of idiopathic and secondary BPPV.

Material and method: 135 patients suffering from BPPV and 140 normal vestibular functioning patients were examined with UC-COMP-CCG. Statistical analysis was completed by using IBM SPSS V24 software.

Results: 109 patients suffered from idiopathic BPPV (i-BPPV), and 26 patients from secondary BPPV (s-BPPV). Parameters indicating the imbalance were observed in both the standing test and the stepping test. Respectively, remarkable results were given in the forehead covering and the self-spin parameter.

Conclusion: By applying and examining both study groups with US-COMP-CCG, we were able to use modern diagnostics and thus have an objective evaluation based on their properties. The objective results from the US-COMPCCG parameters show the deterioration of the vestibular system as well as the change in values, based on the cause of BPPV in secondary cases. 
Keywords: ultrasound-computer-craniocorpography, idiopathic BPPV, secondary BPPV

Maihoub S, Molnár A, Fent Z, Tamás L, Szirmai Á. [Objective diagnostic possibility in the differentiation of idiopathic and secondary benign paroxysmal positional vertigo]. Orv Hetil. 2020; 161(6): 208-213.

(Beérkezett: 2019. szeptember 24.; elfogadva: 2019. október 15.)

\section{Rövidítések}

$\mathrm{BPPV}=($ benign paroxysmal positional vertigo) jóindulatú helyzeti szédülés; $\mathrm{ROC}=$ (receiver operating characteristic) vevő múködési karakterisztika; SE TUKEB = Semmelweis Egyetem, Tudományos Kutatásetikai Bizottság; US-COMPCCG (ultrasound-computer-craniocorpography) ultrahangosszámítógépes kraniokorpográfia

A benignus paroxysmalis positionalis vertigo (BPPV jóindulatú helyzeti szédülés) a perifériás, belsőfül-eredetű szédülés leggyakoribb [1], ugyanakkor jól kezelhető oka [2-4]. Tipikus tünetei közé tartoznak a bizonyos fejhelyzetben kialakuló, pár másodpercig tartó forgó jellegü szédülések, illetve az ehhez társuló vegetatív tünetek (hányinger, hányás) [5]. A betegségben megfigyelhetô egy elég erőteljes női dominancia, és az incidencia a 40-50. életévtől kezdve emelkedik, ahogy ez megfigyelhető a legtöbb perifériás szédüléses kórképben [6]. Korábbi tanulmányokban rámutattak, hogy a sürgősségi osztályon szédülés miatt vizsgált betegek között 8-9\% arányban igazolódott a BPPV mint végleges diagnózis [7]. Az imént említett tünetek a betegek életminőségét jelentősen befolyásolják, így gyakran figyelhető meg szorongás, illetve depresszió társulása [8]. A tünetek kialakulásának feltételezett magyarázata a canalo- és cupulolithiasis. Az utóbbi esetén a magyarázat abban áll, hogy a macula utriculiról leváló kalcium-karbonát kristályok ingerlik a cupula érzékelősejtjeit, ezzel szédülést váltva ki. A canalolithiasis elmélete szerint a hátsó ívjáratba jutó kristályparticulumok a fejhelyzetnek és így a gravitációnak megfelelően szívóhatást gyakorolnak a cupulára [9, 10].

A betegség pontos oka a mai napig nem ismert, az esetek többségében idiopathiás. Ritkábban előfordulnak azonban szekunder esetek, ilyen potenciális ok lehet a háttérben például a fejet érő trauma, posztoperatív állapot, vestibularis migrén, osteoporosis, a vestibularis idegág gyulladása, a belső fül mikrocirkulációjának zavara vagy akár a Ménière-szindróma [11]. Ugyanakkor a más vestibularis eltéréseket (például Ménière-betegség) egyértelmúen befolyásoló társbetegségek - mint a diabetes és a hypertonia - kevésbé gyakorolnak hatást a BPPVre $[12,13]$.

A megfelelő egyensúlyrendszeri múködés érdekében elengedhetetlen, hogy a központi idegrendszerbe befutó vestibularis, vizuális, illetve szomatoszenzoros rendszerekből érkező információkat az agytörzs integrálja, így biztosítva a skeletalis rendszer, az izmok tónusának megfelelő beállítását [14]. Ebben fontos szerepe van a vestibulospinalis pályarendszereknek, amelyek múködése a BPPV-ben megfigyelhető hamis statokineticus információk különbözősége miatt gyakran sérül [15]. Mivel a vizuálisan dependenssé váló beteg esetében a vestibulospinalis tesztekben tapasztalt eltérések csukott szemmel felerősödnek, ezen tünetek objektív vizsgálata, illetve ennek regisztrálása adja az ultrahangos-számítógépes kraniokorpográfia (US-COMP-CCG) létjogosultságát [16].

A BPPV gyakori előfordulása, illetve a szekunder esetek kezelésének eltérő volta, valamint az ultrahangosszámítógépes kraniokorpográf által biztosított differenciáldiagnosztikai lehetôség alátámasztja a téma fontosságát.

\section{Módszer}

\section{Betegcsoport}

Összesen 135, BPPV-ben szenvedő beteg US-COMPCCG-vizsgálatát végeztük el, közülük 109 eset bizonyult idiopathiásnak, míg 26 eset szekundernek. Emellett kontrollcsoportként 140 ép egyensúlyrendszerü alanyt is vizsgáltunk. A betegcsoport részletes ismertetése az 1. táblázatban látható. A betegek komplex otoneurológiai vizsgálaton estek át, ideértve az anamnézis részletes felvételét (különös tekintettel a szédülés jellegzetességeire, illetve a korábban dokumentált pozitív Dix-Hallpike-manóverre, például neurológus vagy sürgősségi ellátást végző orvos által). Tisztahangküszöb-audiometriát, illetve egyéb egyensúlyrendszeri teszteket (elektronisztagmográfia, video-fejimpulzusteszt) szintén elvégeztünk a pontos diagnózis tisztázása érdekében. Az etikai engedély száma: SE TUKEB 190/2015.

1. táblázat |A betegcsoport részletes jellemzése

\begin{tabular}{lccrc}
\hline & $\begin{array}{c}\text { Az esetek } \\
\text { száma }\end{array}$ & $\begin{array}{c}\text { Átlagéletkor } \\
( \pm \mathrm{SD})\end{array}$ & Férfi (\%) & Nő (\%) \\
\hline Idiopathiás BPPV & 109 & $57,09( \pm 11,44)$ & $23(21 \%)$ & $83(79 \%)$ \\
Szekunder BPPV & 26 & $50,5( \pm 13,5)$ & $8(31 \%)$ & $18(69 \%)$ \\
Kontrollcsoport & 140 & $50,8( \pm 15)$ & $43(30 \%)$ & $97(70 \%)$
\end{tabular}

BPPV = jóindulatú helyzeti szédülés; $S D$ = standard deviáció 

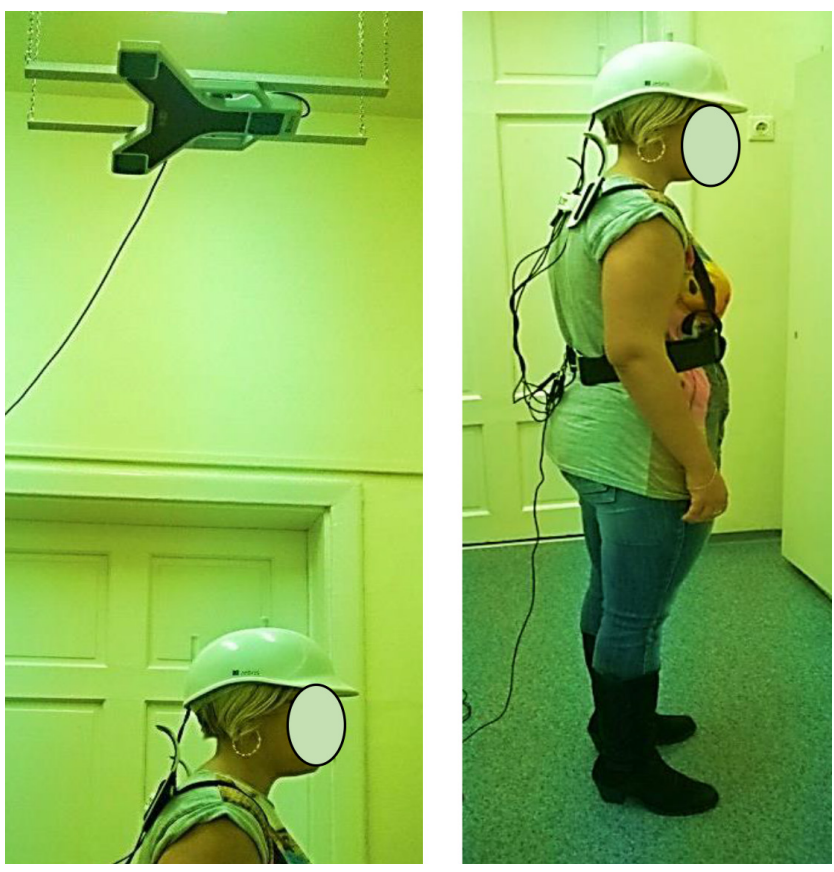

1. ábra

| Ultrahangos-számítógépes kraniokorpográf

\section{Ultrahangos-számitógépes kraniokorpográfia}

Az US-COMP-CCG-t a ZEBRIS Coordinate Measurement System ${ }^{\circledR}$ (Galgenbuhl, Németország) segítségével végeztük el. A páciens egy sisakot visel, amelyen két ultrahangos jeladó található, ezenkívül egy vállra helyezhető egységet szintén két jeladóval (1.ábra). Az adók által kibocsátott ultrahangjelet egy, a plafonra helyezett vevő fogadja be, az így fogadott jelet pedig továbbítja a számítógépnek, amely speciális szoftver segítségével feldolgozza azokat. A kraniokorpográf segítségével két, vestibulospinalis pályát vizsgáló teszt regisztrálható, ezek az állás- (Romberg-teszt) és járásbizonytalanságot (Unterberger-Fukuda-teszt) vizsgálják. Az előbbi esetén a vizsgálati alany egyenesen, lábait összezárva, karjait előrenyújtva áll egy percig. Az utóbbinál a beteget ugyanebbe a pozícióba helyezzük, azonban egy percig tartó helyben járásra szólítjuk fel [17, 18]. A számítógép radarsémában rögzíti a beteg mozgását (2. ábra), és ebből a szoftver megadja a numerikus paramétereket.

\section{Statisztikai elemzés}

A statisztikai elemzést az SPSS V24 szoftver (IBM Corporation, Armonk, NY, Amerikai Egyesült Államok) segítségével hajtottuk végre. Mivel a Shapiro-Wilk-teszt alapján a vizsgált paraméterek nem mutattak normáleloszlást, így nemparametrikus tesztet (Mann-Whitneyféle U- és Fisher-tesztek) alkalmaztunk. A szenzitivitás és specificitás elemzése érdekében ROC-görbéket is analizáltunk. A szignifikanciahatárt minden esetben $\mathrm{p}<0,05$ értékként határoztuk meg.

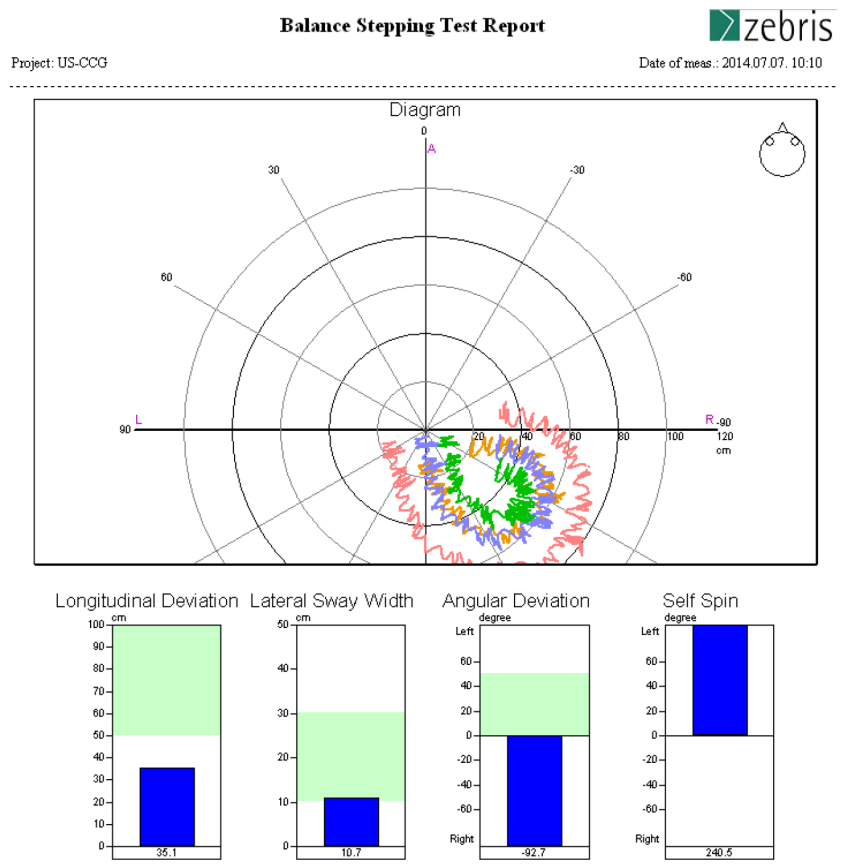

2. ábra

| Ultrahangos-számítógépes kraniokorpogram radarsémában

\section{Eredmények}

Az állás (Romberg-teszt) és a helyben járás (Unterberger-Fukuda-teszt) paramétereit minden betegnél összegyújtöttük, ezek alapján határoztuk meg az átlag \pm SD értékeket. A meghatározott átlagértékek alapján két paraméter potenciális alkalmassága merült fel az idiopathiás és a szekunder esetek elkülönítésében, ezek a 'forehead covering area' (fejmozgás által lefedett terület), valamint a 'self-spin' (tengely körüli forgás) paraméterek. A kontrollcsoport és a BPPV paramétereinek statisztikai összevetését a Mann-Whitney-féle U-teszt segítségével végeztük, amelynek alapján az idiopathiás BPPV- és a kontrollcsoport értékei között nincs statisztikailag szignifikáns különbség. Szekunder BPPV esetén viszont a 'forehead covering area' $(\mathrm{p}=0,005)$ és a 'self-spin' $(\mathrm{p}=$ $0,025)$ paraméterek esetén a különbség szignifikáns, tehát az átlagértékek alapján tapasztalt differencia statisztikailag is alátámasztásra került (2. táblázat).

A paraméterek összevetése érdekében kategóriaelemzést is végeztünk a Fisher-teszt segítségével: ebben az esetben azt vetettük össze, hogy a kraniokorpográf által adott végső eredmény (pozitív/negatív) mennyire korrelál a komplex otoneurológiai vizsgálat végső eredményével (normális egyensúlyrendszer/kóros). Szekunder BPPV-ben a 'forehead covering area' paraméter esetén a p-érték 0,037 , ami utal a korrelációra, idiopathiás eseteknél viszont az eredmény nem szignifikáns $(\mathrm{p}=0,076)$. A 'self-spin' paraméter esetén az eredmények hasonlók, a szekunder eseteknél szignifikáns az eredmény $(\mathrm{p}=$ $0,00001)$, míg az idiopathiásoknál nem $(\mathrm{p}=0,32)$.

A 'self-spin' és a 'forehead covering area' paramétereket boxplotok segítségével is bemutatjuk (3.ábra). Noha 
2. táblázat $\mid$ Az állás- és a járástesztben mért értékek a kontrollcsoportban, valamint idiopathiás és szekunder BPPV-ben

\begin{tabular}{|c|c|c|c|c|c|c|}
\hline & & $\begin{array}{c}\text { Kontroll } \\
\text { (átlag } \pm \text { SD) }\end{array}$ & $\begin{array}{l}\text { Idiopathiás BPPV } \\
\text { (átlag } \pm \text { SD })\end{array}$ & $\begin{array}{c}\text { p-érték } \\
\text { (Mann-Whitney- } \\
\text { féle U-teszt) }\end{array}$ & $\begin{array}{l}\text { Szekunder BPPV } \\
\text { (átlag } \pm \text { SD) }\end{array}$ & $\begin{array}{c}\text { p-érték } \\
\text { (Mann-Whitney- } \\
\text { féle U-teszt) }\end{array}$ \\
\hline \multirow[t]{4}{*}{ Állásbizonytalanság } & $\begin{array}{l}\text { Longitudinal sway } \\
(\mathrm{cm})\end{array}$ & $8,3( \pm 2,8)$ & $2,56( \pm 2,56)$ & 0,32 & $9,45( \pm 4,41)$ & 0,56 \\
\hline & Lateral sway $(\mathrm{cm})$ & $4,2( \pm 1,73)$ & $3,99( \pm 1,32)$ & 1,27 & $5,35( \pm 3,32)$ & 0,72 \\
\hline & $\begin{array}{l}\text { Forehead covering } \\
\text { area }\left(\mathrm{cm}^{2}\right)\end{array}$ & $49,5( \pm 41,02)$ & $34,7( \pm 20,67)$ & 0,18 & $186,49( \pm 278,73)$ & $0,005^{\star}$ \\
\hline & $\begin{array}{l}\text { Torticollis angle } \\
\text { (degree) }\end{array}$ & $8,84( \pm 5,56)$ & $8,56( \pm 5,25)$ & 0,69 & $8,2( \pm 4,77)$ & 0,88 \\
\hline \multirow[t]{4}{*}{ Járásbizonytalanság } & $\begin{array}{l}\text { Longitudinal } \\
\text { deviation }(\mathrm{cm})\end{array}$ & $67,38( \pm 21,87)$ & $67,97( \pm 22,26)$ & 0,84 & $69,66( \pm 27,69)$ & 0,88 \\
\hline & Lateral sway $(\mathrm{cm})$ & $16,42( \pm 7,05)$ & $15,36( \pm 6,04)$ & 0,04 & $15,94( \pm 6,54)$ & 0,63 \\
\hline & $\begin{array}{l}\text { Angular deviation } \\
\text { (degree) }\end{array}$ & $165,27( \pm 10,98)$ & $163,53( \pm 13,03)$ & 0,88 & $161,17( \pm 17,12)$ & 0,33 \\
\hline & Self-spin (degree) & $44,43( \pm 33,15)$ & $35,07( \pm 27,21)$ & 0,05 & $86,33( \pm 78,16)$ & $0,025^{\star}$ \\
\hline
\end{tabular}

A * jelzés statisztikailag szignifikáns különbséget jelöl

$\mathrm{BPPV}=$ jóindulatú helyzeti szédülés; $\mathrm{SD}=$ standard deviáció

a 'forehead covering area' $(\mathrm{p}=0,44)$ és a 'self-spin' $(\mathrm{p}=$ $0,16)$ paraméterek nem különböznek szignifikánsan az idiopathiás és a szekunder BPPV-csoportokban, a boxplotok alapján a két csoport közötti különbségben megfigyelhető tendencia jól látható.

A specificitás és a szenzitivitás meghatározásához ROC-görbéket vettünk fel, és a paramétereket a görbe alatti terület alapján határoztuk meg. Elemzésünk alapján a 'self-spin' paraméter szenzitivitása nagyobb (67\%), és a specificitás is magasnak tekinthető (76\%). Ugyanakkor a 'forehead covering area' paraméter esetén alacsonyabb szenzitivitás (29\%) és specificitás (57\%) tapasztalható (4. ábra).

(a)

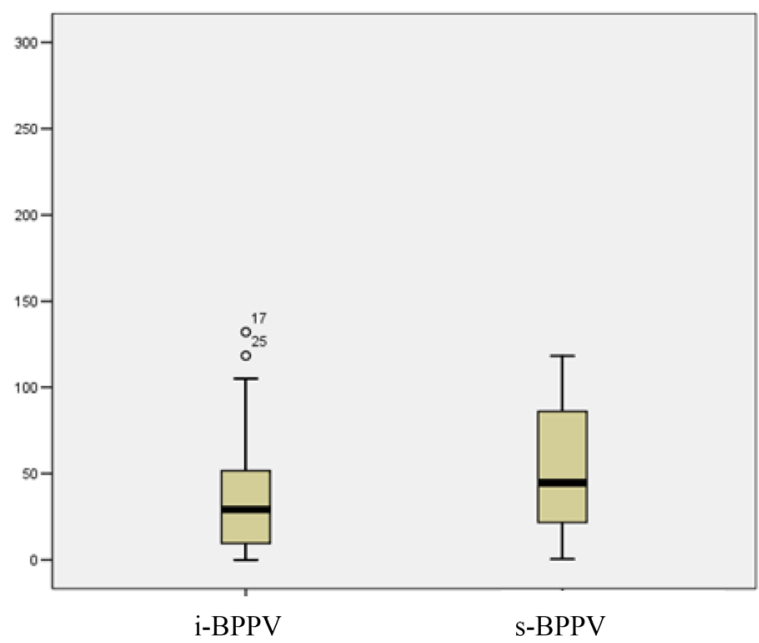

\section{Megbeszélés}

A vestibulospinalis tesztek a belső fül vizsgálatában kiemelt helyen szerepelnek, azért is, mert nemcsak az akut fázisban történő vizsgálatot teszik lehetővé, hanem a betegek követése - akár hosszú távon - biztosítható. A BPPV diagnosztikájának legérzékenyebb eszköze a DixHallpike-manőver, ez azonban sok esetben csak az akut fázisban váltható ki. Mivel a kutatásba bevont betegeink vizsgálata általában az akut fázis lezajlását követően, tervezett időpontban történt, a Dix-Hallpike-manőver gyakran negatív volt [19]. Az anamnézisben fellelhető adatok - úgymint a panaszolt átmeneti halláscsökkenés

(b)

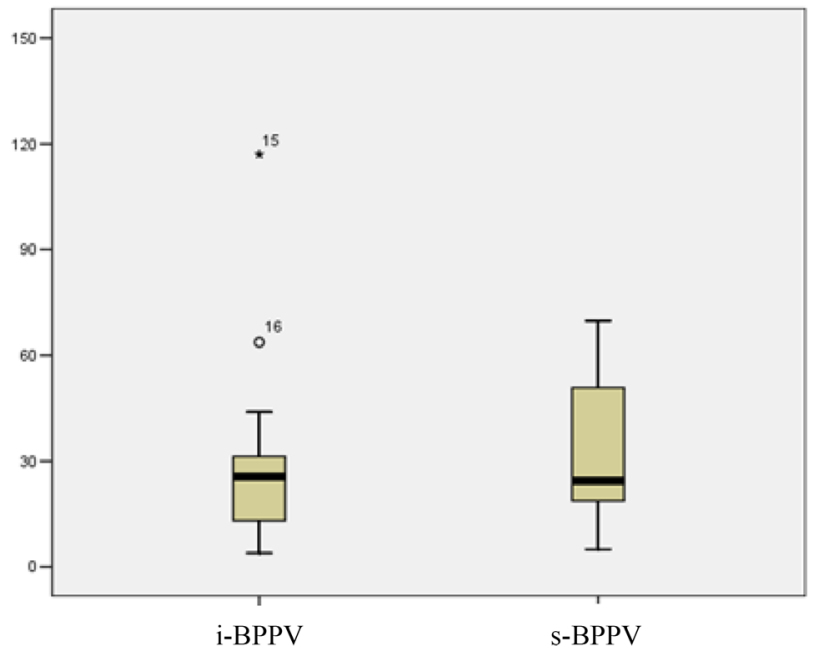

3. ábra $\quad$ A 'self-spin' (a) és a 'forehead covering area' (b) paraméterek összevetése idiopathiás és szekunder BPPV-ben i-BPPV = idiopathiás jóindulatú helyzeti szédülés; s-BPPV = szekunder jóindulatú helyzeti szédülés 
(a)

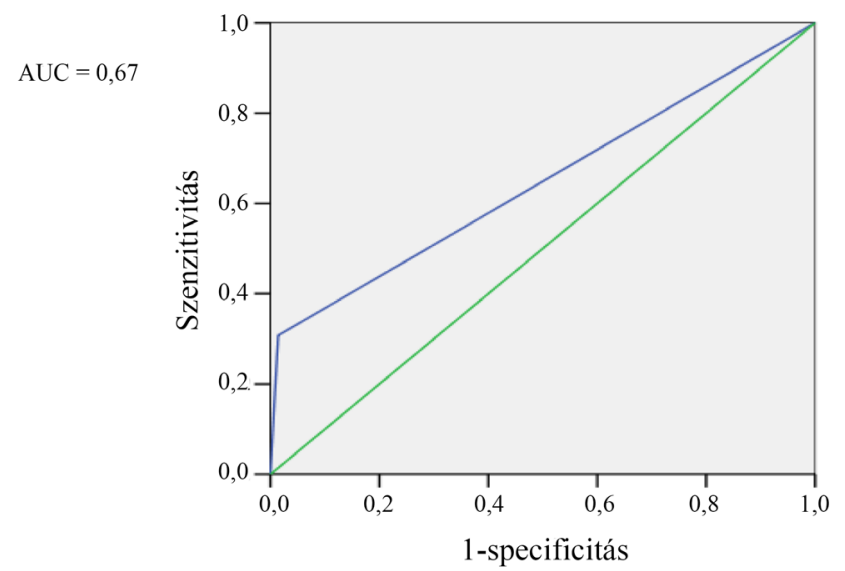

(b)

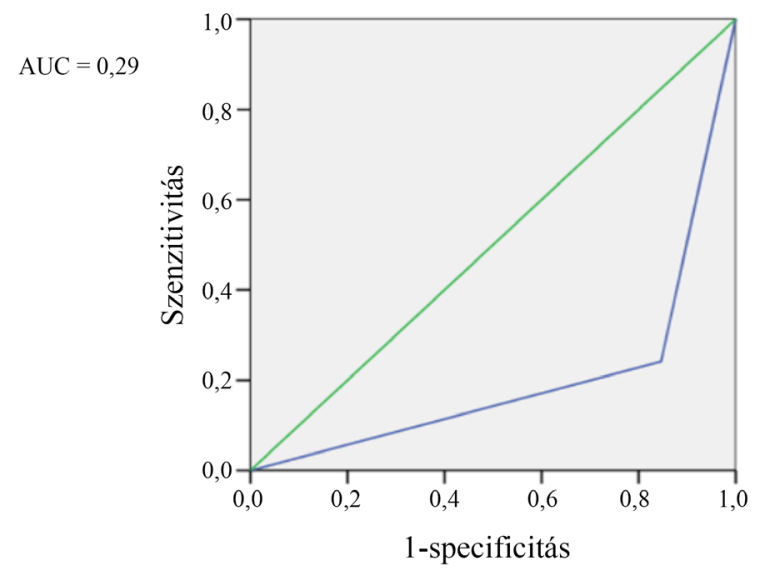

4. ábra

ROC-görbék a 'self-spin' (a) és a ’forehead covering area' (b) paraméter jellemzésére
ROC = vevő múködési karakterisztika

(a Ménière-betegség tünete lehet), vírusos infekciót követően kialakuló hosszan tartó szédüléses epizódok (a neuronitis lehetősége) - miatt fontos lehet kizárni a háttérben álló egyéb lehetséges okokat, például a migrénes eredetet. Az otoneurológiai kivizsgálás részeként a statokineticus próbák minél pontosabb vizsgálatára alkalmas eszköz lehet az ultrahangos-számítógépes kraniokorpográf.

Az ultrahangos-számítógépes kraniokorpográf segítségével az objektív és modern diagnosztika biztosítható, hiszen a vizsgálati eredmények a vestibularis rendszer károsodását alátámasztják. Idiopathiás BPPV esetén a paraméterek kevésbé kórosak, szekunder BPPV-ben viszont patológiás értékek láthatók, elsősorban a 'self-spin' és a 'forehead covering area' paraméterek esetén.

\section{Következtetés}

A fentiek miatt a kraniokorpográf hasznos eszköz, ugyanis modern, objektív, fájdalommentes, gyors, és az eredmény könnyen reprodukálható. A betegek utánkövetésére is alkalmas, nem invazív vizsgálat. A szekunder esetek elkülönítése pedig azért fontos, mert az idiopathiás esetekkel ellentétben azok nem kezelhetők kizárólag repozíciós manőverek (például Epley-manőver) segítségével, hanem a háttérben álló alapbetegség kezelése is szükséges.

Anyagi támogatás: A közlemény megírása, illetve a kapcsolódó munka anyagi támogatásban nem részesült.

Szerzői munkamegosztás: M. S.: A vizsgálatok elvégzése, adatgyüjtés, a kézirat megírása. M. A.: Adatgyüjtés, statisztikai elemzés, kritikai megjegyzések, nyelvi korrekció. F. Z.: Betegbeválasztás, kritikai megjegyzések. Sz. Á.: Témavezető, a beteganyag biztosítása, a kutatás folyama- tos szakmai felügyelete és szupervíziója, kritikai észrevételek. T. L.: Kritikai észrevételek. A cikk végleges változatát valamennyi szerző elolvasta és jóváhagyta.

Érdekeltségek: A szerzőknek nincsenek érdekeltségeik.

\section{Irodalom}

[1] Molnár A, Maihoub S, Tamás L, et al. The follow up of the conservative medical treatment of patients suffering from Ménière's disease. Available from: http://happyvertigo.com/uncategorized/the-follow-up-of-the-conservative-medical-treatment-ofpatients-suffering-from-menieres-disease/ [accessed: September 15, 2019].

[2] Von Brevern M, Radtke A, Lezius F, et al. Epidemiology of benign paroxysmal positional vertigo: a population based study. J Neurol Neurosurg Psychiatry 2007; 78: 710-715.

[3] Marom T, Oron Y, Watad W, et al. Revisiting benign paroxysmal positional vertigo pathophysiology. Am J Otolaryngol. 2009; 30: $250-255$.

[4] Kerrigan MA, Costigan MF, Blatt KJ, et al. Prevalence of benign paroxysmal positional vertigo in the young adult population. PM R 2013; 5: 778-785.

[5] Szirmai Á. Benign paroxysmal positional vertigo. [Benignus paroxysmalis positionalis vertigo.] Hippocrates 2010; 2: 85-87. [Hungarian]

[6] Molnár A, Maihoub S, Tamás L, et al. Intratympanically administered steroid for progressive sensorineural hearing loss in Ménière's disease. Acta Otolaryngol. 2019; 139: 982-986.

[7] Bhattacharyya NP, Gubbels SP, Schwartz SR, et al. Clinical practice guideline: benign paroxysmal positional vertigo (update). Otolaryngol Head Neck Surg. 2017; 156(3_Suppl): S1-S47.

[8] Oghalai JS, Manolidis S, Barth JL, et al. Unrecognized benign paroxysmal positional vertigo in elderly patients. Otolaryngol Head Neck Surg. 2000; 122: 630-634.

[9] Gazzola JM, Perracini MR, Ganança MM, et al. Functional balance associated factors in the elderly with chronic vestibular disorder. Braz J Otorhinolaryngol. 2006; 72: 683-690.

[10] Szirmai Á. (ed.) The differential diagnosis and therapy of balance disorders. [Az egyensúlyzavarok differenciáldiagnosztikája és terápiája.] Semmelweis Kiadó, Budapest, 2006. [Hungarian]

[11] Salvinelli F, Firrisi L, Casale M, et al. Benign paroxysmal positional vertigo: diagnosis and treatment. Clin Ther. 2004; 155: $395-400$. 
[12] Molnár A, Maihoub S, Tamás L, et al. Possible effect of diabetes and hypertension on the quality of life of patients suffering from Ménière's disease. [A diabetes mellitus és a hypertonia lehetséges hatása a Ménière-betegségben szenvedők életminőségére.] Orv Hetil. 2019; 160: 144-150. [Hungarian]

[13] Warninghoff JC, Bayer O, Ferrari U, et al. Co-morbidities of vertiginous diseases. BMC Neurol. 2009; 9: 29.

[14] Szirmai Á, Maihoub S, Tamás L. Efficacy of assisted balance training in chronic vestibular vertigo. [Az asszisztált egyensúlyi tréning hatékonysága krónikus vestibularis rendszeri szédülésben.] Orv Hetil. 2018; 159: 470-477. [Hungarian]

[15] Lacour M, Bernard-Demanze L, Dumitrescu M. Posture control, aging, and attention resources: models and posture-analysis methods. Neurophysiol Clin. 2008; 38: 411-421.

[16] Horak FB, Nashner LM, Diener HC. Postural strategies associated with somatosensory and vestibular loss. Exp Brain Res. 1990; 82: 167-177.
[17] Maihoub S, Tamás L, Molnár A, et al. Usefulness of ultrasoundcomputer-craniocorpography in unilateral Ménière's disease. Biomed Hub. 2019; 4: 500398

[18] Szirmai Á, Maihoub S, Tamás L. Usefulness of ultrasound-computer-craniocorpography in different vestibular disorders. Int Tinnitus J. 2014; 19: 6-9.

[19] Tamás TL, Garai T, Király I, et al. Emergency diagnosis of the acute vestibular syndrome. $[\mathrm{Az}$ akut vestibularis szindróma sürgősségi diagnosztikájával szerzett tapasztalatok.] Orv Hetil. 2017; 158: 2029-2040. [Hungarian]

Molnár András dr., Budapest, Szigony u. 36., 1083 e-mail: andrasm94@gmail.com)

A Semmelweis Egyetem Általános Orvostudományi Kara örömmel tesz eleget annak a hagyománynak, hogy volt diákjait jubileumi díszoklevéllel tünteti ki.

Kérjük ezért azokat az orvosokat, akik diplomájukat az egyetem jogelődjénél, a BUDAPESTI KIRÁLYI MAGYAR PÁZMÁNY PÉTER TUDOMÁNYEGYETEMEN, a PÁZMÁNY PÉTER TUDOMÁNYEGYETEMEN, a BUDAPESTI ORVOSTUDOMÁNYI EGYETEMEN, illetVe a SEMMELWEIS ORVOSTUDOMÁNYI EGYETEMEN

$$
\begin{aligned}
& 1945 \text {-ben } \\
& 1950 \text {-ben } \\
& 1955 \text {-ben } \\
& 1960 \text {-ben } \\
& 1970 \text {-ben }
\end{aligned}
$$

szerezték meg, és szakterületükön legalább 30 évig dolgoztak, nyújtsák be kérelmüket a platina, rubin, vas, gyémánt, illetve arany díszoklevél elnyerése érdekében 2020. április 30-ig, a következő címre, az alábbi jelentkezési lapon.

\section{Semmelweis Egyetem Általános - Orvostudományi Kar \\ Dékáni Hivatal \\ 1085 Budapest, Üllői út 26. vagy 1428 Budapest Pf. 2}

A jubileumi díszoklevelek átadására elöreláthatóan októberben kerül sor. A pontos idöpontról meghívó útján küldünk értesítést.

\section{JELENTKEZÉSI LAP}

\section{arany, gyémánt, vas, rubin és platina díszoklevélhez}

NÉV

(névváltoztatás feltüntetésével)

Születési idő:

Diploma kelte:

Lakcím:

Telefonszám:

E-mail cím:

Utolsó munkahely:

Rövid szakmai önéletrajz:

Aláíásommal hozzájárulok ahhoz, hogy fenti adataimat - az ALUMNI tevékenységgel összefüggésben - a SEMMELWEIS ALUMNI Iroda kezelje.

Dátum:

\section{kérelmező aláírása}

Aláirásommal hozzájárulok ahhoz, hogy a lakóhelyem szerinti illetékes önkormányzat megkeresésére, kerületi ünnepségre történő meghívás céljából az elérhetőségeim kiadásra kerüljenek.
A megfelelő válasz aláhúzandó.
IGEN
NEM

A cikk a Creative Commons Attribution 4.0 International License (https://creativecommons.org/licenses/by/4.0/) feltételei szerint publikált Open Access közlemény. (SID_1) 